\title{
Libertarian Paternalism or Paternalistic Welfarism - NUDGES Viewed through the Orwellian Looking Glass
}

Jaison John*

\begin{abstract}
Libertarian paternalism is often considered as an oxymoron that uses the means of libertarianism to meet the ends of paternalism. It is considered as paternalistic as it covertly transforms into a paternalistic apparatus through the endorsement of the choices the State/authority wants people to make. It is argued that since libertarian paternalism invokes incentives which works differently than coercion, this paper and various other scholars reiterate and respond by arguing that the mere replacement of coercion with incentives does not make libertarian paternalism less paternalistic. A libertarian paternal State exploits the malleability of men to mould their behaviour according to the propositions of the ruling class which the rulers often assert to be in the best interests of the masses. In this article, Orwell's Animal Farm, would be used as an analogy to unpack and conceptually analyse the ethical implications of libertarian paternalism.
\end{abstract}

Keywords: Paternalistic State, Dystopic Politics, Orwell and NUDGES

\section{Introduction}

Libertarian paternalism is a new regulatory philosophy that has gained prominence post the break of the millennium. This oxymoronic view fuses the diametrically opposite ideas of

*Independent scholar; jasonjm@outlook.com 
interventionist paternalism and choice preserving libertarianism. This controversial idea is centred on authorities/choice architects nudging people to make choices that will make their lives "longer, happier and healthier" through the employment of incentives. George Orwell's dystopic novel, Animal Farm speaks, symbolically about how the big brotherly state manipulates the malleability of men to further the interests of the priviledged ruling class.

The paper elaborates the parallels between the dystopian states as described by Orwell and the libertarian paternal State of Thaler and Sunstein. The libertarian aspect of libertarian paternalism is analysed to see whether choice is framed or understood as the preservation of a mere absence of coercion or does it actually refer to the exercise of freedom of choice without fear or favour. The important question in the context of libertarian paternalism concerns with the meaning of "good choice" and "bad choice" and the rationale of the parameters used to validate and evaluate the same. Furthermore, the fundamental question of the role of State intervention, whether for welfare measures or otherwise, are explored in the paper.

\section{Libertarian Paternalism and Orwellian Dictatorship}

"But sometimes you might make the wrong decisions, comrades, and then where should we be? asks Squealer the pig in George Orwell's Animal Farm (2009). Squealer, the chief propaganda administrator of the dystopian Animal Farm uses this unanswered question to take away the right to choose from the Free Beasts of the land. 6 decades later Richard Thaler and Cass R Sunstein responds from the other side of the Atlantic to the Orwellian question penned in 1943. Their response is articulated through their controversial idea of Libertarian paternalism; where should we be if you make wrong decisions shouts out Squealer, "libertarian paternalism", retorts Thaler and Sunstein with aplomb. Ironically, in the novel, Squealer was the companion of the oppressor and under the garb of this possibility of error, Napoleon, the oppressive protagonist decides that the council of pigs (characters in the novel) would take all the important decisions. This method resulted in a paternalistic State. Thaler and Sunstein states that their ideal of Libertarian paternalism wants to bring in a new means in which it 
is legitimate for the choice architect to influence people's behaviour to "make their lives longer, healthier and better" and which allows people who don't conform to the choice and the architects' vision to "go their own way" and "exercise their freedom" (Thaler \& Sunstein, 2008).

Interestingly the Orwellian connection of Libertarian Paternalism does not stop at the dystopian novel Animal Farm. It stretches Orwell's masterpiece 1984 that tells us the tale of a big brother, symbolically referring to the state monopoly through governmental apparatus and "the party" who ruled Oceania not "for its own ends, but for the good of the majority" (Orwell, 1984, p. 339). The protagonist Winston in one of his soliloquies in the novel identifies that the omnipresent party acts for the best interest of the masses for people are "frail, cowardly creatures" who are unable to exercise liberty properly and due to this inability, the masses must be ruled over and systematically deceived by others who were stronger than them" (Orwell, 1984, p. 331). Almost 7 decades after Orwell's protagonist uttered the fateful words "You are ruling over us for our own good,... You believe that human beings are not fit to govern themselves, and therefore - " [big brother must rule us] (Orwell, 1984, p. 331). Richard Thaler and Cass Sunstein in their work Nudge Improving Decisions About Health, Wealth, and Happiness comes up with statements and positions that could be seen as a reminiscent of the dystopic world in 1984, such as the idea presented by the state apparatuses that assert that human beings consider choices in life to be a "nuisance" and therefore prefer default choices (Thaler \& Sunstein, 2000). These default choices, conceived by choice architects work towards the manipulation of the minds of people to move in certain directions and convince people of the fact that it "will make their lives better" (Thaler \& Sunstein, 2000). This, they argue, is the correct approach between multiplicity of choices and interventionist paternalism for ensuring progress and continuity. It is important to note that while Orwell's Big Brother became a 'cult villain' because of his oppressive functioning and is frequently used as a warning against government intervention in the lives of citizens, Thaler and Sunstein has tried to euphemise the 'big brothers' and their behaviours through their conceptualisation of the term "NUDGE" (Thaler \& Sunstein, 2000) which is arguably a refurbished idea, 
similar to the oppressive state functioning as mentioned in Orwell's novels. The only change observable is the addition of the prefix libertarian. Thaler and Sunstein rhetorically reminds the readers of the question, Squealer asks the animals - what if a person makes the wrong choice. In Animal Farm, the animals lost their liberty and the right to choose so that they could avoid the risk of bad choices. The possible implications therefore, are eerily reminiscent of the novel, Animal Farm as well.

\section{Limits of Libertarian Paternalism and NUDGES}

The argument that libertarian paternalism celebrates choice is fundamental to its claims of being different from paternalism. The default is chosen by the choice architect and the choice architect, in most of the cases, has a specific intention in selecting a default. To further the reason behind the default, the choice architect attempts to make the default retain its significance. Furthermore, to protect the default choice, as rightly identified by Sunstein, the choice architects ensure that the burdens or costs imposed on people who do not conform or choose the road prescribed by the choice architects suffer the cost of non-compliance, albeit under the garb of a simplistic notion of 'wrong choices' (Sunstein, 2015). This tendency to force the will of the choice architect on the masses casts doubts on the welfarist claims of libertarianism in this regulatory hybrid. Most of the rights have an affirmative and negative element which when combined allows the exercise or reservation of the right. Right to choose also has these two parts: exercising the right to choose and reserving the exercise as the selector might not take an immediate decision to avoid the costs of exercising the choice. The choice architect under the garb of welfare and best interest of the chooser forcibly binds the chooser to one end of the bargain and imposes all the costs associated with such choice on him in addition to any costs by way of deterrence to prevent the usurpation of the default. On the other hand, of the six letters of the word NUDGES, "N" which denotes incentives is outright paternalistic while two others " $\mathrm{D}$ " of defaults and " $\mathrm{S}$ " representing structuring of complex choices are not always libertarian as they take their shade on the basis of the intentions of the choice architect. The rest 3 are understanding mappings, expecting error and giving feedback 
which are not means to any end but are tools to decipher the chooser's mind and are therefore neither libertarian nor paternalistic.

This paper argues that the incentives cause the problem of redistribution which is a much more paternal and welfarist than libertarian. An Indian State which pays a salary of 100 rupees a day to teenage mothers for each day who are not pregnant would be incurring significant expenses due to the paucity of funds available to the State and it might even be seen as a measure that endorses child marriage or hedonism (if unmarried) in the particular sociocultural context in India. Similarly if the government provides monetary assistance to alcoholics or smokers from the public exchequer, the incentive would lead to a context wherein people who did not indulge in these social evils would pay for those who indulged it; in other words, the alcoholics and smokers would benefit out of their irrational choices qua health at the expense of the rational citizens. The opposition towards these programmes cannot be understood as a sheer malice against any habit or an intervention to assist individuals affected by social evils but rather, it is against calling such policies libertarian as it is actually the authoritarian State working under the guise of working for the welfare of the citizens.

Choice involves the right to choose and the right to not to be discriminated qua the choice in relation to others in the same category. For a policy to be truly libertarian, there should be no loss associated with the choice for the person and no gain should accrue to others which is not a result of special assistance by the State due to promotion of any policy which the person is already in conformity with or is not interested buying into; anything against this would be paternalistic action by the State for promoting its ideal and ensuring conformity with it. The question of incentive gains further significance when one is to consider Sunstein's admission that less educated, less sophisticated and poor are less confidant of making choices and are more influenced by the defaults of the government (Sunstein, 2015). The gullibility of the vulnerable class coupled along with their disadvantaged social position would allow the State to successfully use the incentives to bring these classes within its vision and successfully disarm their 
faculty of choice with the incentives. Paternalism is by definition State/individual interference, through coercion or incentive, under a claim of action for the benefit of the individual and thus incentivising an act is more paternalistic than it is libertarian. This is so because the temptation promoted by the State through the incentives is more likely to have more vantage point for the chooser which will inevitably make him/her to choose the State's option.

Incentives are a bigger tool to make people convinced of the government's propositions about state sponsored wellness and good decisions for life. Incentives unlike coercive tactics are useful as they posit a dilemma or a paradox and the individual seeks to free himself/herself from it by adopting the available 'choices'. Adding further lethality to the argument in favour of incentives is that they can work well with rational argumentative individuals as well. Econ, the economic man of Thaler and Sunstein, who chooses unfailingly well, is also admitted to be tempted by the prospect of incentives (Thaler \& Sunstein, 2008). If the incentives are so powerful that they can convince rational and irrational individuals with more or less same efficacy and make them follow paths they might not have chosen in the absence of such temptations, then any choice made under the influence of an incentive to ensure a better life is nothing but paternalistic welfarism and it has nothing to do with preservation of freedom of choice.

\section{Paternalistic Welfarism - A Disguise}

A closer look at the arguments of Sunstein and Thaler show that the idea that they have proposed is more oriented towards promotion of welfare and has less to do about liberty. The meaning given to the term "Libertarian Paternalism" is paternalism which does not curtail the liberty of people (Thaler \& Sunstein, 2008) i.e, the end of paternalism is sought to be achieved through the means of preservation of liberty. The classic example of the paternalistic welfarism is the book itself which is more than capable of convincing a libertarian to believe that the arch planner's actions are the best course of action that preserves liberty in both long and short terms. The idea that is being argued for is not pertaining to the preservation of liberty but a condition of utilitarian welfarism substantiated with a rhetoric of how inefficient individuals are 
when making difficult choices, and therefore, the arch planners must structure the choice frame in a such a manner that the choices that people make are oriented towards their own good, benefit and welfare.

Once again the spectre of the party that loomed over the men of 1984 comes to prominence here. The antagonist in 1984 asserts that the choice of mankind was "between freedom and happiness" and for most men happiness was better than freedom and therefore, the party is acting for the happiness of the masses (Orwell, 1984). The very title of Thaler and Sunstein's book openly declares that it is inter-alia about improving decisions about happiness. Throughout the book, the sentiment is that NUDGES can improve people's lives and solve society's problems (Thaler \& Sunstein, 2008). The reasons that Sunstein offers for justifying choice architects and their action is quite peculiar; it's his view that choice architecture "help to produce decisions that will make people happier or otherwise better off, and that are either wise or right" (emphasis supplied) (Sunstein, 2015). The important question that arises at this juncture is concerning the location where the element of libertarian choice rests in this policy of decisions for the welfare of the person.

To understand how the framing of choice architecture by government goes against libertarianism, one must see the distinction of the role of government in libertarian and paternalistic systems. In a libertarian system, the role of the government is limited to ensuring the protection of the individual and the safety of the individual (Boaz, 1998). The government is the facilitator who provides a framework that enables the individual to pursue what he deems good for himself with the sole caveat of noninterference with similar rights of others (Boaz, 1998). Any action of the government by which it seeks to do anything more that ensuring safety and being a facilitator the acts would deprive the individual of their rights and liberties (Boaz, 1998). Such overstepping of the government for the purposes of planning the economy, organising the society, regulates the actions of people the government violates and nullifies the very reason of its existence (Libertarianism, 2017). Thus it is clear that any action by government to fiddle with the choices of men is anti-libertarian. 
Dworkin defines Paternalism as "the interference with a person's liberty of action justified by reasons referring exclusively to the welfare, good, happiness, needs, interests, or values of the person"(1972). When the State executes programmes which are aimed at making people go the 'right way' or make 'better decisions for a happier life', it opens itself to be labelled as paternal intervention. Sunstein and Thaler defends libertarian paternalism on the ground that it does not involve coercion and absence of coercion and ensures that it does not restrict choices (Sunstein, 2015). The assumption that coercion is the key element in determining the degree of restriction is not really correct. Paternalism need not always be coercive. Incentives, as demonstrated above, are much more lethal as they infiltrate the mind to let the arch planners do as they desire as opposed to the blunt coercion as a practice or tool of oppression which operates from an external plane. Instead of helping people to tide over the instinctive impulses, lucrative incentives influence people to sell their freedom of choice by accepting the "best choice for life and happiness' as predefined by the government; this solution by nature fetters the development and outsources right to choose to government.

Literature on power classifies power into Power Over and Power To/Social Power (Dowding, 2011). Social Power is the ability to change the incentive structure of another while Power To is the ability to determine the outcome (Marciano \& Josselin, 2007). In a paternalistic system, the government can apply its vastly superior social power to make people reframe their incentive structure by incentivising the choices it expects people to make. Thaler and Sunstein's libertarian aspect of libertarian paternalism is a situation where people are "free to do what they like - and to opt out of undesirable arrangements if they want to do so" (Thaler \& Sunstein, 2008). The immense social power wielded by the State however is not really conducive for the existence of this system. The government can tempt the individual with incentives and manipulate his incentive structure subtly so that the indirect denial of freedom of choice in a situation which is artificially created would ensure a favourable outcome for the government in so far that it may actually be considered as libertarian. In reality, it 
remains as a case of making people want what the government wants them to desire by altering the very rules of game.

The threat of this welfarism is that it is might be the beginning of a continued reaction. The difficulty is in drawing a line for interventionist policies under the name of welfare. Martin Niemöller, the famed anti-Nazi Theologian best captures the result of this dilemma. Seven years of life in concentration camps made Niemöller confess about the short sightedness of his policy of being a mute spectator of Nazi intervention in the following words

When the Nazis came for the communists, I did not speak out as I was not a communist. When they came for the trade unionists, I did not speak out as I was not a trade unionist. When they came for the Jews, I did not speak out as I was not a Jew. When they came for me, there was no one left to speak out for me. (Niemöller, n.d.)

The liberty to take bad decisions is better than dangerous paternalistic government intervention which might take away the very right to take any decision. It's not the welfare motive as envisioned by the government that must be satisfied but my will is to be satisfied in making any personal choice, whether good or bad in the eyes of the government.

\section{Manipulation of Choice and Redistribution of Resources}

Redistribution of resources and unmitigated manipulation of the choice architect are two possible consequences of libertarian paternalism and the occurrence of either strikes at the very root of libertarian values. The US Supreme Court decision in School Dist. of Abington Tp. v. Schempp (374 U. S 203, 1963) illustrates how NUDGES cross the limit and cause redistribution and moulds minds as per the choice architect. First, the case is examined to see how the power to design choice impacts libertarianism. The case pertained to certain provisions of Pennsylvania Prayer Statute which required the reading of 10 verses of Bible at every public school at the beginning of the school day (374 U.S. 203, 1963). Religion was found to be a fundamental part of the public life and the government. The Supreme Court revered religion in several of its practises by invoking the name of God when taking Oaths to 
office, while opening the session of the Congress or the Court (374 U.S. 203, 1963). As religion was a fundamental part of public life, it is for the choice architect to ensure that the masses follow religion and for this he creates a default rule of reading out verses every day. To pass off the measure as non-paternalistic, he "allows" them to choose to opt out of the measure by a written request and an auxiliary provision which bars any comments on the verses read to prevent allegations of indoctrination and propaganda.

The courts, both trial and apex, strikes down the measure despite the provision for exclusion on written request. The key point which does not allow the case to be used as the perfect example is the Constitutional policy of neutrality towards religion in the present case and the legality of the measures to protect the health of people or inculcation of habit if saving for future. Another notable point is an argument by the Appellant that the cost of exclusion almost made the default the only option. To the benefit of Thaler and Sunstein, they have clearly stated that NUDGES are counted as libertarian paternalistic only if the costs of the measures are low. To discern which costs are less and which costs are more, the possibility of power creeps in favour of paternalism in the course of time.

A couple of judgements of the Indian Courts would show how libertarian paternalism can turn into absolute paternalism owing to the clustering of gradual power in favour of paternalism. The Constitution of India (Constitution of India, Section 51-A(a)) and The National Honour Act (The Prevention Of Insults To National Honour Act, 1971) has provisions for the respect of the national anthem. The first case Bijoe Emmanuel \& Ors vs State Of Kerala \& Ors held that standing up at the time national anthem is not disrespectful (All India Reporter, 1987). However, the markedly libertarian temperament qua the national anthem takes a turn for the worse as we move on. The Calcutta High Court in Kamal Dey vs Union of India (Calcutta High Court Notes (Calcutta), 329, 2016) and the Madras High Court in N. Selvathirumal vs Union of India (All India Reporter, 2016) expressly made it compulsory to sing the national anthem in schools. The Ministry of Home Affairs, on receiving the direction of the Calcutta High Court issued orders to the concerned State governments to make national anthem 
compulsory at the beginning of the day's work (Orders Relating To The National Anthem Of India III(5), 2017). To cap everything in Shyam Narayan Chouksey vs Union of India, the Apex Court ordered that it is the duty of every citizen to show respect to the national anthem as it is a symbol of "Constitutional Patriotism and inherent national quality" (Manupatra/Supreme Court Order, 2016). The idea of respect to national anthem changed from a constitutional nudge to paternalistic shove at the end.

In the Indian and American cases what started out as mere show of respect turned out to be a paternal mandate owing to the power that gradually NUDGEd the libertarian element out of the frame. Power to design choice frames, in itself, might not be antilibertarian but the power is the problem. The ends of paternalism would slowly and gradually grow at the expense of the means of libertarianism in libertarian paternalism making it standalone paternalism in due course. The libertarian choice is a mere façade for achieving the end of paternalism. Orwell in Animal Farm explains the culmination of power beautifully (Orwell, 2009). The pigs were just another set of animals in the beginning; later they chaired the Sunday meetings of animals and after some infighting between them; Napoleon, the victor of the fight decided that a committee of the pigs will make decisions for the benefit of all the animals. To the detriment of others, the pigs went on to change the very commandments which were held sacred and they finally teamed up with men whom they had overthrown after a bloodied fight. The trajectory of the power curve mostly starts out as mere directives and ends as outright paternalism, the possibility of irrational choices by oneself is used to take away the right of choice itself.

The impenetrable walls of Troy fell before the Greeks as the Trojan horse infiltrated the mighty walls. State intervention is not being equated to the Trojan horse here, but allowing the State to manipulate the choice is letting the Trojan horse of "best interest decision" into the walls of our liberty to choose. The real possibility of losing liberty by allowing the State to intervene in our choices is a real concern. Sunstein himself moves in this direction when he asserts that the system will tilt towards the abdication of power to 
choose. The automatic system or impulsive system is unruly while the reflective system employs the intellect and faculty of reason and logic to reach conclusions. The ghastly solution offered by Sunstein to avoid the 'bad' decisions arising out of unreal optimism and lack of foresight is to choose 'not to choose' and embrace the defaults that Orwell's 1984 shows us when he provides the glimpse of what might happen if the State decided to manipulate individual's choices. O'Brien, the antagonist in 1984 openly says, "We control life, Winston, at all levels. You are imagining that there is something called human nature which will be outraged by what we do and will turn against us. But we create human nature. Men are infinitely malleable" (Orwell, 1984). This malleability of individuals might be dextrously used by the State to convert its citizens to unthinking puppets.

Redistribution of resources is another point that needs consideration from the School Dist. of Abington Tp v. Schempp decision. Libertarianism might not be antithetical to manipulation of choice but redistribution of resources or bearing of costs for the benefit of another can never be encompassed within libertarianism. The Court affirmed that the tax payer's money cannot be used for the promotion of religion (School Dist. of Abington Tp. v. Schempp, 216). The reasoning for the decision is based on the neutrality of the Government towards religion. The comparison that is sought to be drawn here is that the lines of cases which deal with similar issues and exhibit a common pattern which is action against promotion of beliefs of a certain group. Cases including Engel v. Vitale (370 U.S. 421, 1962), Santa Fe Independent School District v. Doe (530 U.S. 290), McCollum v. Board of Education (333 U.S. 203, 1948) unequivocally hold that promotion of religion by State is illegal as it gives the religion, so promoted, a seal of approval to affect other religions or atheism. The default choice of pro religious policy is advantageous to people who hold certain beliefs and disadvantageous to others. This is opposed to a libertarian view 'making our choices'. Extrapolation of the argument into the realm of taxation would mean that resources of atheist tax payers' would flow for the benefit of faithful taxpayers in case of State sponsored religious activities. The point to be argued is that in a libertarian system, no rights could be given positive assistance (Arneson, 2000) and any assistance rendered by the State for one set of beliefs/practices 60 
invariably will cause a denial of such benefits and imposition of costs in the form of loss of possible benefit on all other nonconformists' lives whether neutral or opposed to the State, and the members of other faiths. The money that would have been used for general public purpose is used for the benefits of these chosen ones causing a redistribution of wealth. As Reiman points out libertarian paternalism is opposed to using an individual as a resource for others as it involves disadvantage (actual or notional) for people who were not conformists to the arch planner's vision without any consent or affirmation from their part (Reiman, 1981).

The Save More Tomorrow Plan is touted as a perfect opportunity to implement libertarian paternalism by setting the default in favour of the plan so that the persons enrolled gets free money from the employer (Thaler \& Sunstein, 2008). The arguments made by Sunstein and Thaler do not consider the problem of exhaustibility of resources of the employer and subsequent detriment that the persons who wilfully made the choice might have suffered owing to en masse enrolment by default. The employer might set up a cap on contribution to reduce the per capita contribution or appropriate funds earmarked for other employee benefits towards this resulting in a gain for the unmindful employee at the expense of the prudent one and if the employer is government then the increase in contributions might be passed on to the taxpayers, causing further redistribution (Mitchell, 2005). The magnitude of the incentive also matters, a dollar a day obesity incentive may turn the head of an unemployed man but for a wealthy individual, it might not even matter as this would be considered as a miniscule incentive and this might lead to a redistribution of wealth (Wikler, 1978). To ensure participation of all classes, the government might need to propose the incentive differently wherein that would imply that it has to negotiate the threat of redistribution looming large over such increased incentives as the larger incentive is the taxpayers' money which would be required to be spent on a wealthy yet not responsible person. Undoubtedly, the redistributive benefits that arise out of such welfarist default might be infinitely better than the libertarian default that denies individual's such benefits. At the end of the day, however, calling such a redistributive welfarist measure libertarian is oxymoronic as libertarianism ends where redistribution begins. 
The asymmetry that these redistributive incentives create is unreasonable and disproportionate. This is not only because it rewards incompetent and irrational decision making of a few and covers the failure of the government to work within its existential causes but also in so far as the promotion of unusual 'best interests' cover the vested interests and prejudice against the fundamental right (the State ought to give) to choose. What it gains, therefore, is a platform to advance parochial political welfarism.

\section{Conclusion}

The authors, Thaler and Sunstein, establish NUDGES as the panacea for the short-termism inherent in humans. However the, salvation is not the nudges but it lies within the NUDGES. Understanding mappings, Giving feedback, Expecting error amongst the NUDGES along with empowerment through information can help people make farsighted decisions that will enhance their liberty. As the authors rightly point out, humans face difficulties in making difficult choices due to lack of information or due to a disregard of attenuating circumstances or due to a sheer bias towards or against certain choices. The solution to this is not outsourcing of the choice to arch planners or usurpation or dilution of power to choose. Instead, strengthening the decision making capabilities of individuals so that the right choose can be exercised in the optimal manner by the individual himself is important and required. Liberty is strengthened when freedom of choice is exercised even when making rare and difficult choices and any attempt to manipulate the mind or directing it to any particular end is blatant paternalism. Thaler and Sunstein could not have been more right when they pointed out that men make better choices when they are aware of what they are doing (Improving Decisions About Health, Wealth, and Happiness, Richard H. Thaler Cass R. Sunstein) and the solution for irrational choices due to ignorance is not outsourcing the choice but teaching men to make better choices. The intention should never be to curtail liberty but enabling people to make informed choices on their own without intervention. 


\section{References}

Arneson, R. J. (2000). Perfectionism and politics. Ethics, 111(1), 37-63.

Boaz, D. (1997). Libertarianism: A primer. Simon and Schuster.

Constitution of India. (1954). Section 51-A(a).

Dworkin, G. (1972). Paternalism. The Monist, 56(1).

Dowding, K. (Ed.). (2011). Encyclopedia of power. Sage.

Gregory, M. (2005). Libertarian paternalism is an oxymoron. Northwestern University Law Review, 99(3), 1245-1277.

Libertarianism. (2017). A short essay on the ideals of libertarianism and the policy of Laissez Faire. Retrieved from http://johnhospers.com/ Articles/GuestEds/ Libertarianism \%20 and \%20the\%20Policy\%20of\%20Laissez\%20Faire.html (accessed 29 July 2017)

Marciano, A., \& Josselin, J. M. (Eds.). (2007). Democracy, freedom and coercion: A law and economics approach. Edward Elgar Publishing.

Martin Niemöller Biography. (n.d.). Holocaust Encyclopaedia. Retrieved from

https:/ / www.ushmm.org/wlc/en/article.php?ModuleId=10007391

Orders Relating To The National Anthem Of India III(5). (2017). Retrieved fromttp://mha.nic.in/sites/upload_files/mha/files/pdf/NationalAn them(E).pdf

Orwell, G. (1989). Nineteen Eighty Four. Penguin books.

Orwell, G. (2009). Animal farm: a fairy story and essays collection. Houghton Mifflin Harcourt.

Reiman, J. H. (1981). The fallacy of libertarian capitalism. Ethics, 92(1), 8595.

Sunstein, C. R. (2015). Choosing not to choose: understanding the value of choice. Oxford University Press, USA.

Thaler, R. H., \& Sunstein, C. R. (2008). Nudge: improving decisions about health, wealth, and happiness. Penguin.

The Commonwealth of Pennsylvania, by law, 24 Pa.Stat. § 15-1516, as amended, Pub.Law 1928 (Supp. 1960) Dec. 17, 1959

The Prevention of Insults to National Honour Act, 1971. Retrieved from https:/ / indiacode.nic.in/bitstream/123456789/1578/3/A1971-69.pdf

Wikler, D. I. (1978). Persuasion and coercion for health: ethical issues in government efforts to change life-styles. The Milbank Memorial Fund quarterly. Health and society, 56(3), 303-338.

\section{Case and Case Reports}

1. All India Reporter 1987 Supreme Court 748 (India).

2. Calcutta High Court Notes (Calcutta). 2016(1) 329.

3. All India Reporter 2016 Madras107. 
4. Manupatra/Supreme Court Order /41605/2016

5. School Dist. of Abington Tp. v. Schempp 216

6. 333 U.S. 203 (1948).

7. 370 U.S. 421 (1962).

8. 374 U.S. 203. (1963). Retrieved from https:// supreme.justia.com/ cases/ federal/ us/374/203/case.html

9. 530 U.S. 290. 